\title{
A STUDY OF MUTUAL INTERPLAY OF MICRONUTRIENTS AND SPECTRUM OF
} DIABETIC PATIENTS

\section{Diabetology}

\section{Dr. Roopal Verma}

\begin{tabular}{l}
\hline Dr. Aanchal \\
Sawhney* \\
\hline Dr. Mridusmita \\
Khataniar
\end{tabular}

MBBS, DNB. Senior Resident, Department of internal medicine, Sir Ganga Ram Hospital, New Delhi.

MBBS, Junior Resident, Rajiv Gandhi Cancer Institute, New Delhi.*Corresponding Author

MBBS, DNB, Senior Resident, Department of internal medicine, Sir Ganga Ram Hospital, New Delhi.

\section{ABSTRACT}

Persistent uncontrolled hyperglycaemia in Diabetes Mellitus causes permanent structural and functional damage to tissues, which leads to micro and macro vascular complications causing increased mortality and morbidity. Magnesium and Calcium are required for Insulin secretion, Iron is essential for cell functioning and zinc forms the structure of insulin. 90 subjects were enlisted in the study after obtaining written informed consent and divided into 3 groups of pre-diabetic, diabetic and diabetic with micro and macro vascular complication.A brief history with relevant clinical examinations using monofilament test and ophthalmoscopic examination were done to evaluate for diabetic neuropathy and retinopathy respectively. Blood samples for serum zinc, calcium, magnesium and iron were collected and analysed with respect to age, gender and duration since diabetes was diagnosed. With increase in duration of diabetes and HbA1c, serum zinc, iron, and magnesium levels decreased, while calcium levels increased. Till date very few studies have been conducted to study micronutrients deficiency in pre-diabetics.Detection of micronutrients deficiency early in the course of diabetes, may delay the development of complications with their supplementation. Hence, this study is being done to study micronutrients in diabetics and pre-diabetic patients.

\section{KEYWORDS}

\section{Micronutrients, Pre-diabetes, Diabetes, Zinc}

\section{INTRODUCTION}

Persistent hyperglycaemia of uncontrolled diabetes is known to cause an alteration in the metabolism of some micronutrients which leads to a vicious cycle of disturbed micronutrients and glucose homeostasis. Some trace elements such as zinc, magnesium, manganese, and selenium potentiate the blood glucose lowering effect of insulin through insulin receptors activation, cofactors, or through antioxidant properties.(1). Many studies have suggested that alteration in the metabolism of these macro and trace elements may be a causative factor for development and progression of diabetes mellitus (2). 90 patients in our study were divided into 3 groups according to ADA guidelines (3).

DiSilvestro in his article on zinc explained that deficiency of zinc might lead to decreased synthesis and secretion of insulin from pancreatic beta cells in diabetes mellitus.(4) A study conducted in Japan showed that autoantibodies against zinc transporter were present in $50-60 \%$ population who had recent onset diabetes mellitus. (5) Iron is a component of antioxidant enzymes such as superoxide dismutase, catalase, and glutathione peroxidase. Oxidative stress is found in diabetes and its complications. (6) Abnormally high blood glucose can cause non-enzymatic glycation of the amino acids found in a protein which produces advanced glycation end products which play an important part in development and progression of diabetes and its complications.(7) Higher levels of serum iron found to be associated with insulin resistance, diabetes mellitus, and its vascular complications.

Magnesium is a micronutrient that is necessary for formation, secretion of insulin and acts as a cofactor for several enzymes involved in normal glucose metabolism.(8) Hypomagnesaemia has been linked to poor glycaemic control, diabetic nephropathy, neuropathy and diabetic retinopathy.(9) Uncontrolled hyperglycaemia also causes reduced efflux of calcium from cells. This increase in calcium entry and decreased exit from the cells results in high concentration of calcium in the cells. (10)

Whether these micronutrients are affected in people with impaired fasting glucose or impaired glucose tolerance is not very evident, as not many studies have been done in these subsets of patients. Hence, this work was undertaken to evaluate levels of serum zinc, iron, magnesium and calcium in prediabetic and in diabetic patients with and without micro vascular complications.

\section{AIMSAND OBJECTIVES}

1. To estimate and compare serum zinc, iron, magnesium, and calcium level in prediabetes and diabetes mellitus patients with and without micro vascular complications.

2. To study association of age, glycaemic status, and duration of disease with the serum concentration of these micronutrients in these subjects.

\section{MATERIALAND METHODS}

In an observational comparison conducted in a tertiary care hospital in North India over 17 months, 90 subjects were enlisted in the study after obtaining written informed consent. These subjects were divided into 3 groups each consisting of 30 people namely, group 1 prediabetic patients, group 2 diabetic patients without complications while group 3 had a population of diabetic patients with micro vascular complications

\section{Inclusion criteria:}

1. Diagnosed cases of prediabetes on the basis of ADA criteria for prediabetes for group 1

2. Diagnosed cases of type 2 diabetes mellitus on basis of ADA diagnostic criteria for diabetes for groups 2 and 3

3. Patients of age group (18-60 years) for all the three groups.

4. Subjects consenting to be a part of the study.

\section{Exclusion criteria:}

1. Subjects with malabsorption syndrome, diarrhoea, pancreatitis, alcoholism, liver disease, chronic renal failure due to factors other than diabetes.

2. Patients with retinopathy or neuropathy due to factors other than diabetes.

3. Patients who were pregnant.

4. Subjects taking micronutrients supplementations

A brief history with relevant clinical examinations using Monofilament test and ophthalmoscopic examination were done to evaluate for diabetic neuropathy and retinopathy respectively. Blood and urine samples were collected for HbAlc, serum zinc, iron, magnesium, and calcium and detection of micro albumin respectively. Data collection and analysis was done hereafter.

The reference range for iron was 50-160 $\mu \mathrm{g} / \mathrm{dl}$ in male and 40-150 $\mu \mathrm{g} / \mathrm{dl}$ in the female, for calcium was $8.2-10.4 \mathrm{mg} / \mathrm{dl}$, for Zinc was 80$120 \mu \mathrm{g} / \mathrm{dl}$ and for Magnesium was 1.7-2.7 mg/dl. (11)

\section{RESULTS}

115 patients were enrolled and finally 90 patients were recruited due to 
refusal and exclusion criteria out of which 30 patients were divided equally into prediabetic, diabetic and diabetics with complications. Of the 90 subjects, 48 were females $(53.33 \%)$ and 42 were males $(46.67 \%)$. In our study, with increasing age, the levels of serum magnesium showed a decreasing trend however, age had no effect on serum levels of zinc, iron and calcium levels.

In this study, the serum zinc, magnesium and iron were normal in prediabetic population and showed a decreasing trend in diabetics with and without complications. On the contrary, serum calcium was normal in pre-diabetics and showed increasing trends in diabetics with and without complications. Similar decreasing trends in serum zinc, magnesium and iron levels were observed in patients with increase in duration of diabetes and $\mathrm{HbAlc}$ levels, however serum calcium followed a decreasing trend with increasing duration of diabetes and HbA1c levels in the above mentioned groups.

\section{DISCUSSION}

Micronutrients play a vital part in the pathogenesis of Diabetes. The serum zinc values showed a decreasing trend across the groups, which may be due to increased loss in urine. Contrary to our study, a previous study done by Rafiqul et al showed a lower level of serum zinc in prediabetics compared to normal and diabetic subjects. (12) Results similar to our study were found in a study done in Punjab, in which low zinc levels were seen in all diabetic patients but the decrease in levels was more in the group with microangiopathic complications .(13)

The mean serum iron values showed decreasing trends of serum iron across the groups. Similar results were found in a study done in Iranian elderly population with significantly low levels of serum iron in diabetic group in comparison to the normal population (14) Mean serum magnesium in group 1 was normal and a decreasing trend was seen in groups 2 and 3.The previous study done by Stricker et al showed low magnesium levels in prediabetics. (15) Mean serum calcium was above the reference range in all groups and a significant difference was found in between the groups. Shimodaira et al also concluded in their study that the albumin- adjusted calcium levels were high in prediabetics.(16) They also observed that higher levels of serum calcium were associated with complications of diabetes.

With respect to age, levels of serum magnesium showed a falling trend with increasing age whereas age had no effect on serum levels of zinc, iron, and calcium. Similar results were explained by Masood et al in their study. (17) In our study, duration of diabetes and $\mathrm{HbA} 1 \mathrm{C}$ also had a significant effect on micronutrients levels. With an increase in duration of diabetes and $\mathrm{HbAlc}$ levels, serum zinc, iron, and magnesium levels decreased, while calcium levels increased.

Correlation study showed a statistically significant negative correlation in between age and serum magnesium among prediabetics (group 1). Among group 2 statistically significant positive correlation found in between $\mathrm{HbA} 1 \mathrm{c}$ and serum calcium. A study conducted by Kanchana et.al. in Chennai showed a negative correlation between serum calcium levels and blood glucose levels.(18) Among group 3, a statistically significant positive correlation was seen in between age and serum magnesium and in between $\mathrm{HbA} 1 \mathrm{c}$ and serum calcium.

\section{CONCLUSION}

Our study suggests that Zinc, iron and magnesium deficiencies are significantly more commonly seen in diabetics with or without complications. Calcium levels, on the other hand, are seen to significantly increase with the disease and its complications. Micronutrients are not a part of mainstream management of diabetes as of 2018. However, as diabetic care advances, in the near future these may become a part of holistic management of the disease and its complications. These alterations in micronutrient levels suggest an intricate relationship of these with diabetes, its duration and its complications and hold promise as a potential avenue of therapeutics in managing this burgeoning disease more effectively.

\section{REFERENCES}

1. Vincent J. B. (2000). Quest for the molecular mechanism of chromium action and its relationship to diabetes. Nutrition reviews, 58(3 Pt 1), 67-72. https://doi.org/10.1111/j. 1753-4887.2000.tb01841.x

2. Siddiqui, K., Bawazeer, N., \& Joy, S. S. (2014). Variation in macro and trace elements in progression of type 2 diabetes. TheScientificWorldJournal, 2014, 461591. https://doi.org/10.1155/2014/461591

3. Kasper DL, Fauci AS, Hauser SL, Longo DL, Jameson JL, et al., editors. Harrison's principles of internal medicine. 19th ed. New york: McGraw Hill;2015.
4. DiSilvestro R. A. (2000). Zinc in relation to diabetes and oxidative disease. The Journal of nutrition, 130(5S Suppl), 1509S-11S. https://doi.org/10.1093/jn/130.5.1509S Kaw https://doi.org/10.1507/endocri.ej12-0069 https://

6. Cai L. (2006). Suppression of nitrative damage by metallothionein in diabetic hear contributes to the prevention of cardiomyopathy. Free radical biology \& medicine, 41(6), 851-861. https://doi.org/10.1016/j.freeradbiomed.2006.06.007

7. Wilson, J. G., Lindquist, J. H., Grambow, S. C., Crook, E. D., \& Maher, J. F. (2003) Potential role of increased iron stores in diabetes. The American journal of the medical sciences, 325(6), 332-339. https://doi.org/10.1097/00000441-200306000-00004

8. Hussain, S., Reza, S., Raza, H., Zafar, S., Ahmad, S., \& Javed, R. (2020). Study of Serum Magnesium levels in diabetic patients with and without retinopathy. The Professional Medical Journal, 27(12), 2656-2661. doi:10.29309/tpmj/2020.27.12.4132

9. Ahmed Baig, M. (2012). SERUM MAGNESIUM AS A MARKER OF DIABETIC COMPLICATIONS. Journal Of Evolution Of Medical And Dental Sciences, 1(3), 119123. doi: $10.14260 /$ jemds $/ 20$

10. Massry, S. G., \& Smogorzewski, M. (1997). Role of elevated cytosolic calcium in the pathogenesis of complications in diabetes mellitus. Mineral and electrolyte metabolism, 23(3-6), 253-260

11. Lopez J. (2013). Carl A. Burtis, Edward R. Ashwood and David E. Bruns (eds): Tietz Textbook of Clinical Chemistry and Molecular Diagnosis (5th edition): Elsevier, St. Louis, USA, 2012, 2238 pp, 909 illustrations. ISBN: 978-1-4160-6164-9. Indian Journal of Clinical Biochemistry, 28(1), 104-105. https://doi.org/10.1007/s12291-012 Journal $0287-7$

12. Islam, M. R., Arslan, I., Attia, J., McEvoy, M., McElduff, P., Basher, A., Rahman, W. Peel, R., Akhter, A., Akter, S., Vashum, K. P., \& Milton, A. H. (2013). Is serum zinc level associated with prediabetes and diabetes?: a cross-sectional study from Bangladesh. PloSone, 8(4), e61776. https://doi.org/10.1371/journal.pone.0061776

13. S.B. Nayyar, M. P. U. G. (2013). COMPARATIVE STUDY OF SERUM ZINC, MAGNESIUM AND COPPER LEVELS AMONG PATIENTS OF TYPE 2 DIABETES MELLITUS WITH AND WITHOUT MICROANGIOPATHIC COMPLICATIONS. Innovative Journal of Medical and Health Science, 3(6). Retrieved from http://www.innovativejournal.in/index.php/ijmhs/article/view/551

14. Mohammadian, M., Milani, A., Hassas, M., Rashidi, S., Asl, E., Rostaminasab, S., . . younesi, F. (2015). Evaluation of Serum Iron, Zinc and Their Relationships with Glycemic Control Status in Iranian Elderly Women with Type 1 Diabetes Mellitus. Journal of Pharmacy and Pharmacology, 3. doi: 10.17265/2328-2150/2015.09.002

15. Kieboom, B., Ligthart, S., Dehghan, A., Kurstjens, S., de Baaij, J., Franco, O. H., Hofman, A., Zietse, R., Stricker, B. H., \& Hoorn, E. J. (2017). Serum magnesium and the risk of prediabetes: a population-based cohort study. Diabetologia, 60(5), 843-853. https://doi.org/10.1007/s00125-017-4224-4

16. Shimodaira, M., Niwa, T., Nakajima, K., Kobayashi, M., Hanyu, N., \& Nakayama, T. (2015). The relationship between serum calcium level and early-phase insulin secretion (2015). The relation endocrinology \& diabetes . Official journal, German Society of Endocrinology [and] German Diabetes Asoci 139438217.Masood, N., Baloch, G. H., Ghori, R. A., Memon, I. A., Memon, M. A., \& Memon, M. S. (2009). Serum zinc and magnesium in type-2 diabetic patients. Journal of the College of Physicians and Surgeons--Pakistan: JCPSP, 19(8), 483-486.

18. N, K., \& P, S. (2014). Serum Calcium Levels In Type 2 Diabetes Mellitus. IOSR Journal Of Dental And Medical Sciences, 13(8), 01-03. doi: 10.9790/0853-13820103 